\title{
F.P. Viljoen
}

\section{HOSEA 6:6 AND IDENTITY FORMATION IN MATTHEW}

\begin{abstract}
Matthew uses Hos. 6:6 in two scenes of conflict between Jesus and the Pharisees. He defines the differences between Jesus and the Pharisees in terms of adherence to the Law with focus on the mercy that God desires. Matthew depicts Jesus as one who teaches and enacts Hos. 6:6 in continuity with the original prophetic intention of this statement. Jesus teaches by example by enacting mercy towards the marginalized and people in need. He loves the way Hosea announces that God intends his people to love. Jesus Himself becomes the presence and source of mercy. Jesus forms the central focus and prototype of the Matthean community. The community should follow his example.
\end{abstract}

\section{INTRODUCTION}

The quotation of Hos. 6:6 ( $\varepsilon^{\prime} \lambda \varepsilon \circ \varsigma$ $\theta \dot{\varepsilon} \lambda \omega$ xai ou $\left.\theta v \sigma^{\prime} \alpha \nu^{1}\right)$ in Matthew's Gospel plays an important role in Jesus' arguments to defend his and his disciples' actions against the accusations of the Pharisees ${ }^{2}$. This reference forms the central argument in two scenes of conflict between the Pharisees and Jesus. The first scene describes Jesus defending his table fellowship with tax collectors and sinners after the calling of Matthew (Matt. 9:9-13). The other describes Jesus defending his interpretation of the Sabbath law (Matt. 12:1-14).

The appearance of this quotation is striking for at least two reasons. Firstly, this citation in Matthew is unique among the parallel Synoptic narratives, but is uttered twice in Matthean material. This verse is even

1 "I desire mercy, not sacrifice".

2 The way Matthew describes the Pharisees is polemic. The issue about the correspondences between the Pharisees in the text and the Pharisees in history (in the time of Jesus and in the time of Matthew) should be considered.

Francois $P$ Viljoen, Faculty of Theology, North-West University (Potchefstroom campus), PO Box 6001, Potchefstroom, 2520, E-mail: viljoen.francois@nwu.ac.za 
absent from the entirety of the rest of the New Testament. This suggests that the verse is of particular importance to the first evangelist. Secondly, in both of these scenes Jesus is in dispute with the Pharisees and is accusing their conduct. The accusation of bad conduct is a theme of Hosea 6 too $^{3}$.

The Gospel writer addressed particular situations and issues of his own time and this is most probably what is reflected in the text (Carter 2000:7; 2004:74-77). The author of the Matthean gospel formed part of an early Christian congregation and he wrote his gospel with his congregation and its issues in mind (Luz 2005:17; Saldarini 1991:39). The two episodes discussed in this article probably reflect issues of conflict with the Pharisees in the Sitz im Leben of Matthew and his community. In the manner Matthew tells the story, he draws the religious and social issues of his original readers into the discourse (Kingsbury 1988:3) and integrates applicable arguments into his narrative (Osborne 2010:25).

Evidently Hos. 6:6 was important for Matthew and his community in order for them to define their identity and maintain their identity against the new post-70 AD Jewish establishment. It seems as if the community suffered some kind of conflict with a Pharisaic component of their society (Carter 2000:32; Keener 1999:46; Luz 2005:244; Repschinski 2000:329; Saldarini 1991:49). Matthew clearly identifies the Jewish leaders as Jesus' opponents. He describes Jesus as the undisputed victor in all these confrontations. Hinkle Edin (1998:355) fittingly remarks: "For Matthew the difference between Jesus and his adversaries is based on Hosea 6:6". A similar observation was made by Schlatter (1959:308):

Der Spruch (Hos. vi.6) hat sicher in der Wirksamkeit Jesu und weiter im Verkehr der ersten Christenheit mit der Judenschaft eine grosse Bedeutung gehabt, da er den Gegensatz zwischen Jesus und dem Pharisäismus bis in die letzten Gründe hinein beleuchtete.

Matthew and his community are involved in an ongoing Auseinandersetzung with Judaism (Hill 1978:117). Like the Pharisees, Matthew's community recognized the law, though they differed in interpretation of what the law meant in practice (Carter, 2004:75-76; Hill 1972:117). "E $\lambda \varepsilon \circ \varsigma$, as expressed in the double quotation seemingly formed

3 In Hos. 6:6 Yahweh speaks of his frustration with the fleeting devotion of Israel. $\mathrm{He}$ declares the reason of issuing judgement against them. He asserts that He wants true piety and not mere outward pretention of religious zeal (Garrett 1997:160; Limburg 1988:27). 
their key to the true Erkenntnis of the will of God and of the law (Bornkamm, 1963:26; Trilling, 1964:83) ${ }^{4}$.

Kilpatrick (1950:59-100) draws attention to the educational role and communal orientation of the first gospel. The gospel does not merely have an informational, but also formational function. It intends to shape its community by telling them about how Jesus instructed his disciples to live a distinctive way of life (Combrink 2006:26-27).

The aim of this article is to establish the significance of the double reference to Hos. 6:6 in two scenes of conflict in Matthew's gospel. Several issues will receive attention in an attempt to reach this aim. Firstly, the article will consider how the original setting of the quotation in Hosea contributes to the reading of the text in its Matthean contexts. Then the meaning of the quotation in its Matthean settings will be established. The meaning is sought not only to understand what Matthew's Jesus intended with these references, but also how these stories reflect the situation of the Matthean community. The way Matthew used these stories to form the communal identity of his community will consequently be considered.

\section{THE FORM AND SETTING OF THE QUOTATION}

As illustrated below, the Matthean form of the quotation offers a wordby-word translation of the Hebrew of the Masoretic text, though it differs slightly from the most common LXX (Rahlfs) version.

\begin{tabular}{|c|c|c|}
\hline Matthew & 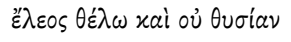 & I desire mercy and not sacrifice \\
\hline Masoretic text & 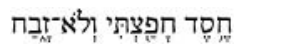 & I desire mercy and not sacrifice \\
\hline LXX & 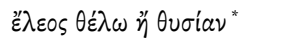 & I desire mercy rather than sacrifice \\
\hline
\end{tabular}

* In some versions of the Vulgate this variation of the LXX is rendered as "plus quam" rather than "et non".

Matthew uses the Jewish Scriptures quite extensively. Several studies have been devoted to this matter (e.g. Menken 2004; McConnell 1969). Matthew often does not wholly stick to the precise wording or plain sense of the text he cites. Prophetic words are often newly rendered and

4 The third occurrence of $\varepsilon^{\prime} \lambda \varepsilon \circ$ in in the first gospel is in Matt. 23:23: "You give a tenth of your spices - mint, dill and cumin. But you have neglected the more important matters of the law - justice, mercy ("z $\left.\lambda \bar{\varepsilon}_{\mathrm{c}}\right)$ and faithfulness". It is once again unique to Matthew and appears in context of criticism of the Pharisees (and teachers of the law) (Hill 1977:110). 
interpreted within the context of Jesus-events (Müller 2001:321). Moule blames Matthew of ignoring the original meaning of words and taking them out of context. He regards Matthew's appeals to the Jewish Scriptures "manifestly forced and artificial and unconvincing" (Moule 1977:129). France (1998:182), however, points out that Matthew's method of using the Jewish Scriptures should be understood within Matthew's understanding of its fulfilment in Jesus. Matthew recognized a further dimension of continued divine purpose of text, a sensus plenior that comes to light in ongoing revelation. Thus Matthew does not set the meaning of the original text aside, but places it in the wider context of divine actions. Yet in the two citations of Hos. 6:6 by Jesus in Matthew, the Masoretic text was precisely rendered and it seems that the original context indeed contributed significantly to the understanding of Matthew's text. The LXX variant rather seems to be a careful reinterpretation of the text to avoid reading the text as if Hosea radically repudiates the whole sacrificial cult with its impious feastings.

In the original prophetic context of Hosea the theme of covenantal loyalty is dominant (Garret 1997:160; Limburg 1988:28-30; Repschinski 2000:79). It refers to the proper behaviour or partners in a covenantal relation. It suggests loyalty and constancy, as well as indicating love (Morris, 1981:71). Yahweh remains true to his covenant with his people. This should also be the attitude of people who are in a covenantal relationship with God. They should show constant loyalty and love towards God and his people.

In parallel form Hos. 6:65 identifies the two great desiderata of Yahweh, mercy and knowledge of God. He contrasts this with sacrifice and burntofferings, which Yahweh despises:

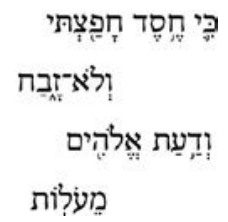

Mercy involves goodness and kindness in moral behaviour, a loving and compassionate heart that is associated with dedication to God. This should be paired with knowledge of God, which implies true recognition of Yahweh's nature and will. These two desires of Yahweh stand in contrast to the cultic feasting and burnt offering that He despises (Macintosh 1997:234). The question arises whether the Hebrew idiom conveys a

5 For I desire mercy, and not sacrifice, and the knowledge of God rather than burnt-offerings. 
negation of the sacrificial system as such. Macintosh (1997:234) chooses for this interpretation. However, an alternative interpretation is possible where Hosea does not condemn sacrificial worship as such, but the faulty reliance upon it amidst moral corruption. Such rituals are meaningless without the faithful love of the worshippers (Beare 1981:227; Garret 1997:161). In such a case the rituals actually had become obstacles to true devotion (Garret 1997:161). Israel's covenant with Yahweh requires devotion that goes far beyond the mere adherence to rituals (Stuart 1987:110). In this sense Hosea therefore expresses the divine demand for 7 (mercy) rather than sacrifice. All six the occurrences of חृ in Hosea $(2: 19 ; 4: 1 ; 6: 4,6 ; 10: 12$; 12:6[12:7]) appear in a covenant context and in close association with other covenantal terms. Hosea speaks against religious acts without inner piety (Turner 2008:153). Steadfast love, devotion and fidelity to Yahweh are required (Zimmeli 1985:382). Israel's love is not steadfast. Israel's love is short-lived as fleeting dew or cloud cover that disappears with sunrise. Furthermore, their devotion is not characterized by any expression of mercy. They keep to the letter of the law in observing sacrifice, but not to the heart of it, as they lack mercy and love (Osborne 2010:337). They are neither loyal to God nor to their fellow Israelites (Hos. 4:1-2).

The Matthean Jesus most probably quotes this verse in line with the intention of Hosea. In both cases He uses Hos. 6:6 to condemn the rigid and inhumane attitudes of the Pharisees of his day. He accuses them of a lack of mercy towards people and knowledge of the will of God.

\section{THE CITATION OF HOSEA 6:6 IN MATT. 9:13}

The first scene in which Hos. 6:6 is quoted falls within a block of ten healing miracles separated by discipleship sections in sets of three (Matt. 8-9) (Kingsbury 1988:59; Osborne 2010:332; Overman 1996:112). Encounters of conflict between Jesus and the religious leaders surface on several occasions: when Jesus forgives a paralytic his sins (Matt. 9:3), when $\mathrm{He}$ sits at a table with tax-collectors and sinners (Matt. 9:10-11), when Jesus' disciples do not fast (Matt. 9:14) and when He exorcises a demon (Matt. 9:32-34). Jesus' forgiveness of sins leads to his ministry to sinners, the downtrodden and despised (Matt. 9:9-13). Matthew contrasts inadequate responses to Jesus' call with what should be the proper response (Osborne 2010:332).

Matt. 9:9-12 describes the scene where Jesus calls Matthew and has a meal with marginalized people of the Jewish society. It expresses God's mercy for outsiders of the community and the constitution of a new community. In the meantime the conflict with the religious leaders grows. 
I The call of Matthew to become a disciple (Matt. 9:9)

(9:9): Setting of the scene

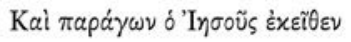

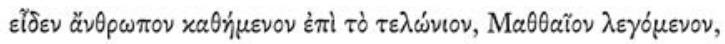

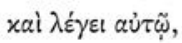

'Axo

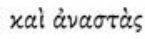

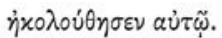

II The table fellowship with sinners (Matt 9:10-13)

(9:10): Development of the scene

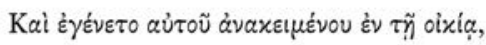

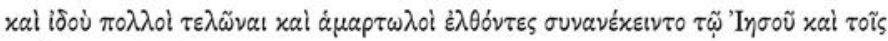

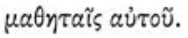

(9:11): Objection by the Pharisees

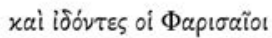

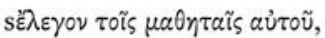

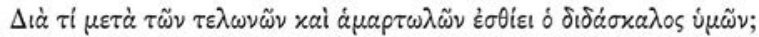

(9:12): Jesus' response

$\delta \delta \dot{~} \dot{\alpha} x \circ v_{\sigma} \sigma \alpha \varsigma \varepsilon \tilde{l} \pi \varepsilon \nu$,

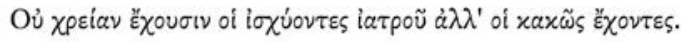

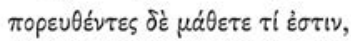

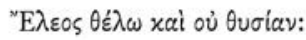

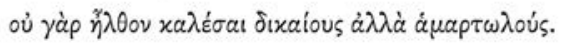

The scene is set by Jesus who calls Matthew the tax collector (Matt. 9:9). The Gospels attest that tax collectors ${ }^{6}$ were deeply despised as unpatriotic and were associated with shameful characters such as beggars, thieves and adulterers (cf. Matt. 5:46. Luk. 3:12-13; 5:29-30; 7:34, etc.). "Tax-collectors and sinners" represent a disgraceful formulaic pair in the Synoptic Gospels (Overman 1996:126). In the parlance Jesus shows mercy to this marginalized figure and calls him into a new relationship with

6 Though the tax collectors had some political and economic power, they had little social status. They were despised as agents of Roman oppression and regarded as greedy and self-serving (France 2008:171; Hagner 1993:238; Senior 1998:105). Others in the empire shared this view of tax collectors. Cicero (De office. 15-51), Diogenes Cynicus (Ep. 36.2) and Dio Chrysostom (Orat 14.14) lump them together with beggars, thieves and robbers. Tax collectors were regarded among the very low level of imperial society (Overman 1996:127). 
Him that is merciful (Carter 2000:219). Matthew obeys and follows Jesus. Matthew picks up this theme of discipleship from Matt. 8:18-22. The word

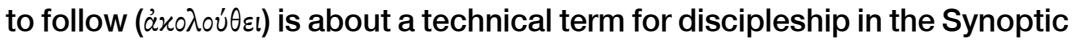
Gospels (Senior 1998:104). The present imperative indicates a continuing following, which describes a call of discipleship (Morris 1992:219).

The story then continues with Jesus having dinner with "tax collectors and sinners" in Matthew's house (Matt. 9:10). Table fellowship was regarded as an important symbol of closeness of those participating (Blomberg 2005:15; Hagner 1993:238).

Some Pharisees ${ }^{8}$ severely questioned Jesus' disciples for this deed of Jesus (calling Him "your master") by using the typical Matthean "our and your/their" language (Matt. 9:11). By his act Jesus expresses full acceptance of tax collectors and sinners. Table fellowship with tax collectors and sinners is described as objectionable to Pharisaic practice ${ }^{9}$. Association with sinners would make a person unclean and therefore unsuitable to participate in sacrifice (Turner 2008:252). Yet Jesus follows an inclusive approach and eats with people excluded and disapproved of by Pharisees. In conflict with the Pharisees' religious pre-occupations, Jesus eats with people whom they judge fit only for the judgment of God. As agent of God's mercy He demonstrates the meaning of mercy (Carter 2000:219).

Jesus himself responds in three parts that assert his authority. Mark and Luke include the first and third parts of Jesus' response, but Matthew alone mentions Jesus' citation from Hos. 6:6. Thus Matthew's version validates Jesus' mission by a scriptural reference to God's will. While the Pharisees regarded Jesus' action as socially and religiously unacceptable, Jesus validates his action with reference to the Prophet as acts of mercy (Mounce 1991:84). By implication the Pharisaic attitude is presented as unmerciful and contrary to Scripture.

7 Illustrating the closeness as symbolized by this meal, Smith (1980) claims that Jesus' meals as depicted in the Gospels must also be understood in terms of Greek symposia.

8 In Matthew's narrative it is the Pharisees alone who reproach Jesus, while Mark mentions "the scribes and the Pharisees" and Luke "the Pharisees and the scribes".

9 Pharisees were scrupulous regarding what they ate and with whom they shared their meals. For the sake of righteousness they were guardians of separation from sinners (Hagner 1993:238; Morris 1992:221; Osborne 2010:336; Overman 1996:129). They were careful to keep themselves unspotted by association with whom they regarded as sinners (Beare, 1981:227). "Keep thee far from an evil neighbour and consort not with the wicked" ('Abot 1:7) was the rabbinic dictum. 
In the first part of his response Jesus uses a proverb that has several parallels in the ancient world" ${ }^{10}$ : "It is not the healthy who need the doctor, but the sick" (Matt. 9:12). The sick are Matthew and the tax collectors and sinners with whom Jesus eats, while those who are well refer to those who regard themselves as religiously knowledgeable. Jesus is the doctor enacting God's mercy towards the tax collectors and sinners. Jesus breaks the tragic effect of sin. In the biblical text the images of sin and disease are closely related ${ }^{11}$. Death is regarded as the ultimate consequence of sin. Sickness lies between sin and death. It is the sequel to sin and the prologue to death. Underlying this connection is also the social implication of both illness and healing (Senior 1998:106).). Illness leads to isolation and exclusion while healing results in reconnection with the community. Jesus facilitates such reconnection by eating with these people.

Jesus then continues by referring to Hos. 6:6 and suggests that the Pharisees, who prided themselves of their knowledge of Scripture, should go and learn what it means that God desires mercy and not sacrifice (Matt. 9:13a) ${ }^{12}$. With this reference, Hos. 6:6 is used as source of halakha, thus arguing the practical application of this prophetic saying. It is appropriate, but also ironic that Jesus answers the Pharisees with a citation from the Scriptures, as they prided themselves on their knowledge of and faithfulness to God's revelation (Davies \& Allison 2004:104). The

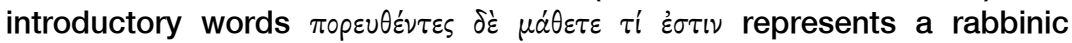
formula to encourage pupils for Torah study ${ }^{13}$, which means "go and discern the sense of Scripture" or "go and make a valid inference from the scriptural statement" (Davies \& Allison 2004:104; Hill 1978:111; Osborne 2010:337). Jesus argues that the fact that the Pharisees accuse Him of eating with the marginalized proves that they do not understand the true meaning of being merciful. Thus the Pharisees become ironic and tragic figures in the narrative (Repschinski 2000:80). The Pharisees are regarded as people who are unable to interpret Scripture correctly, while Jesus' association with tax collectors and sinners are regarded as the expression

10 Davies \& Allison (2004:103) lists "For the one whose body is ill needs a physician" (Menanander, Fragment 591); "Physicians are not among the healthy but spend their time among the sick" (Plutarch, Apophthegmata laconic, 230F); "Physicians are commonly with the sick but they do not catch the fever" (Diogenes, Laertius 6.1.1).

11 It is noteworthy that Hos. 6:6 appears in context of the sickness of the Lord's people as result of their sins (Hos. 5:12-14; 6:1, 5) and their call for repentance so that they can be healed (Hos. 6:2-3) (Van Bruggen 1990:159)

12 This is a powerful comeback. Since they called Him teacher (Matt. 9:11), Jesus gives them a teaching assignment (Osborne 2010:227).

13 Rabbinic parallels to this phrase are found in Seder Eliyahu Rabbah 18 and m. 'Abot 2.9 (Turner 2008:253). 
of indiscriminate and steadfast love. Jesus exercises the true intention of this prophetic word.

The implications of Matthew's understanding of "I desire mercy, not sacrifice" should be considered. Meier (1980:94) argues that this verse implies a complete rejection or temple sacrifice. However, this seems improbable as Matthew says nothing else about temple cult ${ }^{14}$ (Mounce 1991:113). Matthew rather relates to the prophet who did not intend to abolish the temple, but to reform it by stressing inner purity and not mere ritual purity (Turner 2008:253). Another option would be that Matthew portrays Jesus as exalting compassion above strict adherence to the law (Cope 1976:67). Carson (1984:225) proposes a similar interpretation, arguing that this antithesis should not be understood as an absolute negation of sacrifice. It is cast in a Semitic antithesis, where "not A but B" means "B is of more basic importance than A". Such an interpretation makes the understanding of Matt. 5:17 about the continuing validity of the law problematic. Jesus does not downplay the law and sacrifices, but argues that adherence to the law starts with a compassionate heart (Turner 2008:254). It seems more probable that Matthew's understanding

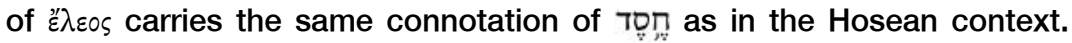
Cultic observance without covenant loyalty is worthless. Jesus warns the Pharisees that they are repeating the same error as Israel in Hosea ${ }^{15}$. By their very desire to maintain the Law, they actually turn away from the covenant and their professed love for the Law become like a morning cloud, like the dew that evaporates quickly (Hos. 6:4) (Repschinski 2000:80). With this reference Matthew's Jesus affirms that God requires faithful adherence and love for God and merciful actions, and not heartless sacrifice or mere formal religious piety, as was the case with Israel in the Hosean text (Turner 2008:253). Jesus argues that the way the Pharisees treat others, demonstrates their failing relation to God (Osborne 2010:337). By not having a heart of mercy towards the sinners, the Pharisees show their inappropriate relation to God (Hill 1978:109).

The showing of mercy signifies more than mere pity and compassion. Lohmeyer (1958:173) made a noteworthy remark about Matthew's reference to Hos. 6:6: "Hier liegt der Gegensatz zwischen Erbarmen und

14 It should be noted that 'Aboth R. Nat. 4 cites Hos. 6:6 in a lament by Rabbi Johanan ben Zakkai over the destruction of the temple: "My son, be not grieved; we have another atonement as effective as this. And what is it? It is acts of loving kindness, for it is said: 'For I desire mercy and not sacrifice'". Davies (1964:306) connects this reinterpretation with the fall of Jerusalem He teaches that sacrifice will be continued by compassionate deeds after the destruction of the temple.

15 In Matt. 23 the Pharisees are accused of a lack of steadfast love. 
Opfer, zwischen christliche Caritas und jüdischen Gottesdienst”. With this quotation the separation between the community that follows Him and the Judaists are signified. The quotation indicates a removal of boundaries between Jesus and the outcasts. Counter to Pharisean convictions, Jesus welcomes these religious outcasts and grants them fellowship. The identity of Matthew's community is moulded on the person of Jesus. His followers would do the same.

In conclusion Jesus describes his own mission with an $\tilde{\eta} \lambda \theta_{0}$-saying ${ }^{16}$ that states the character of his mission: "For I have not come to call the righteous, but the sinners" (Matt. 9:13b). Calling the despised and eating with the marginalized are the ways in which Jesus carries out his mission.

Following the example of Jesus to accommodate outsiders in their community, the Matthean community would experience similar opposition as that of Jesus. The Matthean community was struggling to establish its identity within a post-70 AD Jewish society (Saldarini 1991:49). Jewish Christians welcomed Gentile Christians into their community, but were blamed for it (Luz 1990:84; Repschinski 2000:27), similar to the blame Jesus received for eating with sinners and tax collectors. Elements of identity formation can be recognized in this story. The tax collectors and sinners, who were welcomed by Jesus, probably represent the Gentile Christians in Matthew's community. Matt. 21:31 ("tax collectors and prostitutes are entering the kingdom of God ahead of you") probably relates to the same dispute. The evangelist in Matt. 9:9-12 may have the fellowship of his Jewish-Christian community with Gentile Christians in the church in mind. He defends their stance by appealing to the example of their Master and the conception of his mission on earth, which they have inherited. His community does not regard themselves as the healthy who have no need of a doctor, but as sinners who have been healed by Jesus. They welcome those into their fellowship whom Jesus calls, though they might not meet the standards of legal purity that were set by the Pharisees. By implication Matthew suggests that those who accuse his community for this action must also go and learn what Hos. 6:6 means. Hummel (1966:40) remarks accordingly: "Die Aufnahme der Heiden in die Gemeinde geschieht im Gehorsam gegenüber dem Gebot des Erbarmen ... über den kultisch-rituellen Vorschriften". Obedience to God would result in the removal of social and religious barriers between Christians from the Jews and Christians from the Gentiles. The ultimate opposers of such an inclusive community are the Pharisees.

16 This is the third of the seven "I have come"-statements in Matthew: Matt. 5:17 (2x); 9:13; 10:34 (2x); 35; 20:28) which explains Jesus' God given mission. 
Jesus in Matt 9:13 uses the quotation of Hos. 6:6 effectively to illustrate the religious short-sightedness of the Pharisees. Thus Matthew legitimizes the approach of his community towards people who are regarded as outsiders.

\section{THE CITATION OF HOS. 6:6 IN MATT. 12:7}

In Matt. 12:1-14 Jesus is involved in a debate about the Sabbath praxis, which was central in Jewish religious life ${ }^{17}$. This probably reflects something about the situation of the original audience of the gospel. There is little reason to doubt that there were frequent debates between Christian and non-Christian Jews in the society about Sabbath observance, especially as long as the synagogue was still a matter of concern for the Christians of the Matthean community (Beare 1981:269; Hill 1978:116; Yang 1997:99). It might be that members of this community were accused by Pharisaic Judaism for what they regarded as Christian laxity in Sabbath observance. The story teaches that the law of love and the commandment "to do good" should be fulfilled on the Sabbath. Matthew's story "legitimiert die Freigabe des Sabbats für die Liebestat gegenüber dem Pharisäismus" (Hummel 1966:45). Matthew demonstrates the implications of Jesus' words: "All the Law and the Prophets hang on these two (love) commandments" (Matt. 22:40).

I Harvesting grain on the Sabbath (Matt. 12:1-8)

(12:1): Setting of the scene

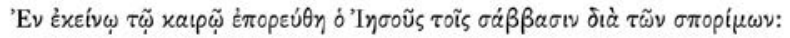

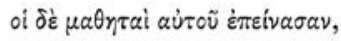

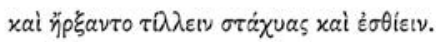

(12:2): Objection by the Pharisees

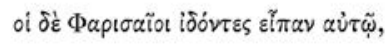

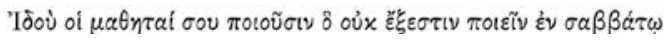

17 In the time of Jesus the Sabbath was well established as one of the central characteristics of the Jewish religion. The Jews had at least three stipulated lists of categories of prohibited works on the Sabbath (Jb. 50.6-13; CD 10.1411.18; $\mathrm{m}$. Sab. 7.2). Through the centuries up to 100 C.E. rules regarding works prohibited on the Sabbath increasingly became more specific and meticulous. However, the emphasis on covenantal significance of the Sabbath was significantly weak (Yang 1997:97-99). 
(12:3-8): Jesus' response with questions and statements

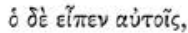

Rhetorical Question 1: Haven't you read (3b-4)

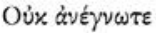

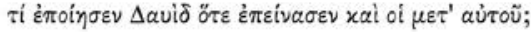

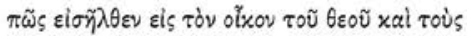

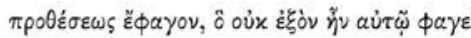

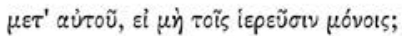

Rhetorical question 2: Or haven't you read (5)

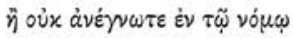

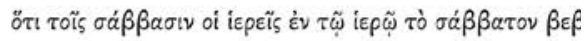

àvaitıoi siøเv;

Statements (6-7)

Jesus greater than the Sabbath

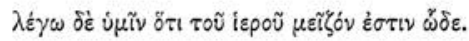

God's demand for mercy rather than sacrifice

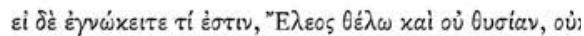

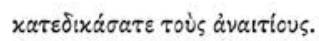

\section{Concluding pronouncement (8)}

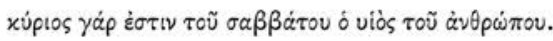

II Healing the man with the withered hand (Matt. 12:9-14)

(12:9-10a): Setting in the synagogue

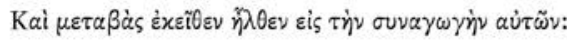

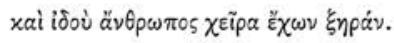

(12:10b-12): Sabbath controversy with the Pharisees

Question of the Pharisees (10b)

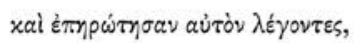

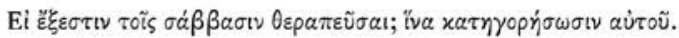

Response of Jesus (11-12)

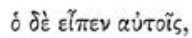

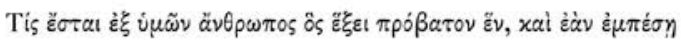

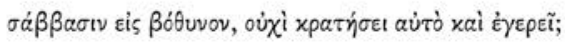

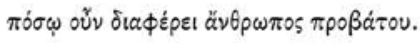

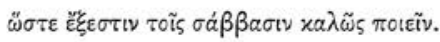


(12:13-14): Contrasting conclusion

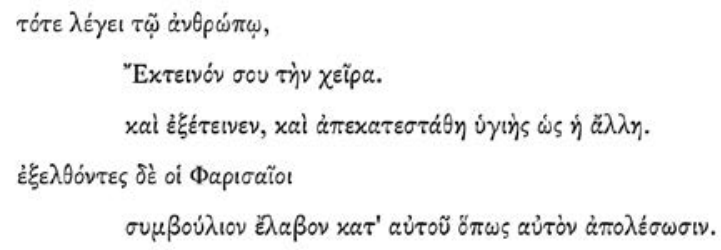

In this episode Jesus responds with several arguments to the Pharisees' when they accuse the disciples of plucking grain on the Sabbath18. In one of his arguments He appeals to Hos. 6:6 again. Once more it is only Matthew who includes this citation in a story that appears in all three the synoptic gospels. This citation emphasises a basic hermeneutical difference between Jesus and the Pharisees regarding the Sabbath law (Overman 1996:176; Turner 2008:309). Matthew includes this citation as it expresses Matthew's main argument that the Pharisees are assiduous about legal observance while they neglect the crucial matter of mercy and loving kindness ("z $\lambda \varepsilon \circ \varsigma)$.

Matthew links this episode about the Sabbath with Jesus' character in the previous chapter. In Matt. 11:28-30 Jesus invites all who are wearied and burdened to find their rest with Him. Furthermore, this link is preceded by Jesus' remark about the lack of understanding by the "wise and learned" (Matt. 11:25), which may refer to the Pharisees who, with all their regulations about legal righteousness, were laying burdens on others instead of giving them rest.

Matthew then continues by telling that the disciples were hungry and began to pluck corn to eat (Matt. 12:1). Mark only describes them going through the corn fields when plucking the grain (Mark 2:23). Matthew probably referred to the hunger of the disciples to demonstrate the correlation between situation of the disciples with that of David and his companions later in the argument (Matt. 12:3-4) (Hill 1978:114; Lohmeyer 1958:184). More reasons for Matthew's elaboration of the story can be considered. Schlatter (1959:308) proposed that Matthew's reference to the disciples' hunger proves that needs take precedence over

18 Sabbath observance was regarded as of greatest importance in Judaism (Beare 1981:269). The Mishnah recognizes that the written law was far less comprehensive than the traditional rules of application. It devotes the whole of Shabbat 7 to what is considered as work on the Sabbath. These rules treated the plucking of a bit of grain as reaping and the rubbing of them in the hands as threshing. Tractate Hagigah 1.8 states: "The rules about the Sabbath ... are like mountains hanging on a hair, for Scripture is scanty and the rules many". 
commandment. However, it is very unlikely that Matthew would argue that God's commandments could be set aside in times of need. Carter (2000:264) argues that this scene concerns fundamental issues of access to food resources and the alleviation of human need. While the dispute is about interpreting the divine will for the Sabbath, critique is extended against systems that hinder access to resources. It is indeed possible that some kind of counter narrative can be involved in this scene. Doing good, especially for the needy, appears to be an important issue for Matthew's community. The denial of access to the grain is not mentioned in the narrative and most probably was not the issue ${ }^{19}$, but the fact that the plucking took place on the Sabbath. Work on the Sabbath was not permitted in the Biblical text (Ex. 20:8-11; 31:14; 34:21; Deut. 5:12-15), yet this controversy presupposes not only the law of the Sabbath rest as laid down in the Ten Commandments, but also the regulations that were developed by the scribes (Beare 1981:269). The point at issue is whether the slightest form of gleaning is permitted on the Sabbath. Kilpatrick (1950:116) proposes that the disciples accidently broke the law, but Jesus does not admit that in the narrative and it is very improbable that Matthew would entertain a conviction that Jesus would find the accidental breaking of the law acceptable.

The Pharisees confront Jesus in asserting their conviction rather than questioning Him. In their accusation they explicitly refer to the law: "your disciples are doing what is unlawful on the Sabbath" (Matt. 12:2), an accusation that Matthew retains from Mark's account. Jesus does not dispute what the disciples have done, but challenges them on the evaluation of their action. He responds by referring to the story about David and the bread of presence in 1 Sam. 21 (Matt. 12:3-4). In that story David and his men were hungry and were therefore permitted to eat the shrine's holy bread, though the law stipulated that only the priests were allowed to do that (Lev. 24:5-9) ${ }^{20}$. David was not punished by God. He seems to approve the deed and strengthens David to continue his task. Likewise, Jesus supports his disciples. Jesus argues that Sabbath praxis should be shaped by mercy.

Matthew requires more than reference to the actions of David to justify the conduct of the disciples (Hill 1978:114) and makes an addition to

19 There is little reason to doubt the Pharisees acceptance of the law that the hungry were entitled to food as a gift (Lev. 25:35-37) and that they could glean after harvest (Lev. 19:9-10; 23:22; Deut. 23:25).

20 According to some Rabbinic traditions David did so on a Sabbath, as the Sabbath was the day that the bread was changed (France 2008:206; StrackBillerbeck 1965:618). Though this is not explicitly mentioned in Matthew's narrative, it might be implied. 
Mark's version. In Matt. 12:5-6 Jesus makes a second biblical allusion by referring to the commands for Sabbath offering (Num. 28:9f). In order to make such an offering, the priest routinely had to "break the Sabbath", yet they were regarded as guiltless. Jesus argues that Sabbath observance must be qualified in relation to greater divine demands.

It is remarkable that Matthew (like Luke) omits Jesus' statement "the Sabbath was made for man, not man for the Sabbath", which is included in Mark's version (Mark 2:27). This implies that the Sabbath should be regarded as a gift from God to man. This statement has Rabbinic parallels (Strack-Billerbeck 1965, II: 5) and could dismantle much of the Pharisees' criticism.

Matthew, however, replaces this statement with a different Christological statement that certainly would have upset the Pharisees: "I tell you that one $^{21}$ greater than the temple is here" (Matt. 12:6). As the temple has been the focus of God's presence amongst his people, so it is now in Jesus that God is to be found much better (France 2008:207). A Christological argument is presented as Jesus presents Himself as God's agent and the one through whom God carries out functions associated with the temple (Carter 2000:266). What God does in his sending of Jesus by far surpasses what He did when setting up the temple worship (Morris 1992:303; Senior 1998:137). The point is that temple service took precedence over the Sabbath, and Jesus' ministry and messianic office supersedes the temple service (Osborne 2010:453). Jesus has even greater authority over the Sabbath.

The worship that God desires is specified by Jesus' citation of Hos. 6:6: "I desire mercy, not sacrifice" in Matt 12:7. This citation explains what Jesus meant by his statement about something that is greater than the temple. France (2008:207) makes a fitting remark by stating that Matt. 12:7 has the same effect as the pronouncement in Mark 2:27: "The Sabbath was made for man, not man for the Sabbath". The outward sacrificial service is contrasted by the spiritual sacrifice offered by Jesus and his disciples.

21 It should be considered that the comparative $\mu \varepsilon \tilde{i} \zeta \delta v$ is in the neuter form. It could therefore be argued that it could better be translated with "something" and not with "someone". However, similar neuter uses of $\mu \varepsilon \tilde{i} \zeta \zeta^{\prime} v$ appear in Matt. 12:4142 that undoubtedly refer to the persons of Jonah and Solomon in contrast to Jesus Himself. Turner (1965:21) remarks that grammatically the neuter can be used to refer to persons provided that the emphasis is less on the individual than on some outstanding general quality. Gundry (1994:223) explains this specific occurrence accordingly as he remarks that the neuter gender stresses the quality of Jesus' superior greatness rather than his personal identity. 
Their sacrifice is characterized by mercy and "doing good on the Sabbath" (Matt. 12:12). Gerhardsson (1974:28) remarks:

The comparison here is between two kinds of worship: the latreia which the priests perform in the temple, and the latreia in which Jesus and his disciples are engaged.

The question remains as to what Jesus meant by this quotation. Scholars have suggested a variety of explanations:

- Strecker (1971:32) proposes that Jesus contrasted ritual law with moral law, but the plucking of the grain can hardly be regarded as the implementation of a moral law (Banks, 1975:117).

- Hagner (1993:330) suggests that "mercy" should be regarded as tolerance towards the disciples for their behaviour. A similar interpretation is made by Hare (1993:132) according to which Jesus wishes the Pharisees to have mercy on the disciples. Yet, interpretations such as of Hagner and Hare imply that the disciples indeed had broken the law. This would not fit into Jesus' argument in the pericope as He states that if the Pharisees understood the meaning of Hos. 6:6, they "would not have condemned the innocent" (Matt. 12:7). It rather seems that Jesus do not merely tolerate his disciples or ask the Pharisees to do the same. He argues that they did nothing wrong in terms of the true intention of the law. He furthermore criticises the Pharisees for their attitude, not because of their lack of tolerance, but because of their misunderstanding of the will of God (Yang 1997:184).

- Another explanation would be to regard acts of mercy as superior to sacrifices. Rabbis recognized the importance of mercy. Already in the third century BCE Simon the Just had said: "By three things is the world sustained: by the Law, the (temple-) service, and by deeds of loving kindness" (Mishnah Abot 1.2) and a teaching attributed to Johanan ben Zakkai after the destruction of the temple reads that the practice of loving kindness replaces the temple worship (Abot R. Nat. 4). Accordingly, Jesus did not argue that the disciples' actions should mercifully be accepted, but that they themselves behaved according to the principle of mercy (Saldarini 1994:130). Being merciful towards themselves, the disciples would therefore be permitted to alleviate their own hunger. However, this interpretation of Matt. 12:8 also does not really satisfy. The only need that could override Sabbath regulations was the threat of death (France 2008:206). There is no indication that the hunger of the disciples was life-threatening and this interpretation 
still implies that the disciples had broken the law, which Jesus does not admit.

- A more satisfactory explanation is that the quotation primarily relates to the character of God (France 2008:168; Hill 1978:118-119). In a loving covenantal relation God shows mercy towards people and He expects a response of loving kindness rather than heartless sacrifice from people. Davies \& Allison (2004:Il:105) thus remarks: "cultic observance without inner faith and heart-felt covenant loyalty is vain".

- This last explanation seems to be the most probable. Jesus argues that there is a relation between God's merciful character and the Sabbath (Yang 1997:186). The Hebrew Bible taught that the Sabbath should not be regarded as a burden, but as an expression of God's mercy and grace. Practicing mercy is the divine will for the Sabbath (Carter 2000:266). If piety hinders practicing mercy, that kind of piety is wrong. Green (1975:125) remarks: "the Pharisees were so anxious to study what Scripture said that they could not hear what Scripture meant". The Lord expects Israel to call the Sabbath a "delight" (Isa. 58:13), and $\mathrm{He}$ regards Sabbath assemblies as vain if they are conducted by people who behave unmerciful (Isa. 1:15-17). This seems to be Jesus' intention with his reference to Hos. 6:6. If one legalistically keeps the Sabbath without understanding that the expression of mercy and grace is the intention of the Sabbath, God would not be pleased with such a person.

Matthew presents Jesus as the fulfilment of the Sabbath with another Christological assertion. Jesus states: "the Son of Man is the Lord of the Sabbath" (Matt. 12:8). The more fundamental question is who has the authority to interpret the Sabbath law. This forms part of Matthew's broader argument that Jesus is the authoritative and definite interpreter of the Torah ${ }^{22}$ (Hagner 1993:330). As Son of man Jesus does not break the Sabbath law, but claims to have the authority to interpret it in a way that undercuts the legalism of the Pharisees (France 2008:208). His teaching legitimizes a merciful life-giving praxis as the divine will (Carter 2000:266). The Pharisees' regulations to observe the Sabbath paradoxically fought God's purpose with it.

Directly after the discussion of the meaning of the Sabbath, Matthew describes Jesus performing an act of mercy; He heals a man with a withered hand. Jesus here does something that is asked from Him in the

22 I argued this issue in my article on the foundation meaing of the Law (Viljoen 2011). 
first gospel repeatedly "Son of David, have mercy ..." (Matt. 9:27; 20:3023; 15:2224; 17:15, etc.). Jesus becomes the presence and source of mercy. Five of the seven occurrences of the verb "ُ $\lambda^{\prime} \varepsilon \varepsilon \dot{\omega} \omega$ in Matthew occur within the context of healing stories. Before being healed, people ask for mercy (Matt. 9:27; 15:22; 17:15). In the case of the healing of the man with the withered hand, Jesus does not respond to such a request from the man, but as an answer to the question whether it is lawful to heal on the Sabbath. Legitimate adherence to the law is expressed in merciful actions to a person in need (Hinkle Edin 1998:357). Jesus demonstrates the difference between adhering to God's intention with the law and the Pharisees' rulebound approach.

Matthew describes the Pharisees as people with a lack of understanding (cf. Matt. 11:25) as they fail to recognize the association between law observance and mercy (Hinkle-Edin 1998:360; Repschinski 2000:101). They did not understand who Jesus was and did not recognize his messianic ministry. Therefore they reacted negatively on Jesus' act of mercy and went out to conspire against Him (Matt. 12:14). The Pharisees are portrayed as involved in a misplaced mechanical and burdensome observance of the Sabbath law. Such observance contradicts God's intention (Turner 2008:310).

As with the story of Jesus who calls Matthew and has a meal with marginalized people of the Jewish society (Matt. 9:9-13), the story on the Sabbath (Matt. 12:1-14) also exhibits some elements of identity formation of the Matthean community. Seemingly this community was accused of laxity in Sabbath observance by Pharisaic Judaism. This story, however, proposes that Sabbath observance remained an important matter in their community. However, the way they observed it, differed from the depicted legalistic approach of the Pharisees. For the Matthean community Sabbath observance should entail experiencing God's rest and mercy and by showing constant loyalty and love towards God and his people.

\section{CONCLUSION}

The passage "I desire mercy not sacrifice" (Hos. 6:6) forms an important hermeneutical key for Matthew. In chapter 9 Jesus tells the Pharisees to "go and learn" the meaning of this passage. In chapter 12 their failure to learn results in Jesus stating that they do not know what this passage

23 The blind men (or in Mark and Luke's case, blind man) ask for mercy in all three the synoptic Gospels (Matt. 9:27; 20:30; Mark 10:47; Luk. 18:38).

24 Matthew adds a request for mercy to the story of the woman asking Jesus to heal her daughter (Matt. 15:22; Mark 7:24ff). 
means. Jesus emerges as informed in understanding how the law actually relates to social relations and Sabbath observance.

Matthew uses Hos. 6:6 in two scenes of conflict between Jesus and the Pharisees. He defines the differences between them in terms of adherence to the Law with focus on the חסֶֶ (' constant covenantal loyalty and love towards God and his people. Such mercy is of fundamental importance for understanding the will of God as expressed in the Law.

Matthew depicts Jesus as one who teaches based on his own authoritative interpretation of the Law and the Prophets. His interpretations frequently differ from the tradition, though his interpretation of Hos. 6:6 reflects continuity with the original intention of that statement in its prophetic context. Jesus also teaches by example by enacting mercy towards the marginalized and people in need. He loves the way Hosea announces that God intends his people to love. Jesus Himself becomes the presence and source of mercy. Thus He fulfils the intention of this prophetic saying.

By his calling and association with the marginalized of the community, the tax collectors and sinners, Jesus offers steadfast love. By defending his disciples and healing the man with the withered hand He again demonstrates what the mercy of God entails. Mercy is found in and with Him. Matthew thus argues that if one wants to adhere to God's will, one should learn to recognize the steadfast love of God for his people as is taught and enacted by Jesus.

These stories probably express certain issues in Matthew's community. These stories demonstrate how his community interprets the law. The experience of this community may not have been very different from that of Jesus Himself. With reference to Matt. 9: 9-13 Matthew and his community need to overcome religious and social barriers to bringing outsiders into the church. The Pharisees in the narrative become some sort of theological construct for a rejecting generation in his contemporary situation. The Christian community is probably confronted with some attitudes of exclusiveness that would hinder them in offering mercy towards those who are considered to be the marginalized and outsiders in a Jewish society. Those who oppose the acceptance of these people should go and learn what Hos. 6:6 means by observing the teaching and behaviour of Jesus. With reference to Matt. 12:1-13 Matthew justifies what they considered as doing good on the Sabbath. It might be that they were accused of laxity in Sabbath observance. The story teaches that the law of love and the commandment "to do good" should be fulfilled on the Sabbath. The 
expression of mercy and steadfast love of God in attitudes and actions of consideration and kindness are promoted.

Markers of identity formation can be recognized in these stories. It is therefore probable that Matthew used these stories as part of his construction of the communal identity of his community and to legitimate their lifestyle. Focus around a central figure typically is such a marker. Jesus forms the central focus and prototype of this community. Another typical marker is that a community follows its leader's teaching and example. Jesus calls his disciples to follow Him. As part of this community one should obey his teaching and imitate his covenantal steadfast love and mercy in accepting and serving others. As central figure and prototype of the community $\mathrm{He}$ is the authoritative interpreter of the Scriptures and the enactment of God's will and covenantal loyalty and steadfast love. In the social organization of the community each follower should realize that he or she is a sinner who needs Jesus as doctor. Members of the community should follow the prototype and act in an appropriate manner. Each member should be willing to practice inclusive mercy towards outsiders and marginalized people. Unique practices and rituals develop. Within this community Sabbath observance is characterized by doing good and helping the needy. This mindset fashions a life style according to God's will. The community is warned against opponents. The Pharisees are regarded as the opponents of the Matthean community, since they fail to understand the meaning of the Scriptures. The community is warned not to be intimidated by the Pharisees or to act like them.

\section{BIBLIOGRAPHY}

BANKS, R.

1975. Jesus and the law in the synoptic tradition. Cambridge: University Press.

BEARE, W.B.

1981. The Gospel according to Matthew. A commentary. Oxford: Basil Blackwell.

Blomberg, C.L.

2005. Contagious holiness: Jesus' meals with sinners, New Studies in Biblical Theology (NSBT). Downers Grove, III: InterVarsity Press; Apollos: Leicester, U.K.

BornKamm, G.

1963. Tradition and interpretation in Matthew., New Testament library. London: SCM Press.

Carson, D.A.

1984. Matthew. The expositor's Bible commentary. Grand Rapids: Zondervan. 
Carter, W.

2000. Matthew and the margins: $A$ socio-political and religious reading. Sheffield: Academic Press. (Journal for the Study of the New Testament Supplement Series 204).

2004. Matthew, storyteller, interpreter, evangelist. Massachusetts: Hendrickson.

Combrink, H.J.B.

2006. The challenge of overflowing righteousness; to learn to live the story of the gospel of Matthew. In J.G. Van der Watt. (ed.) Identity, ethics, and ethos in the New Testament. (Berlin \& New York: Walter de Gruyter), pp. 23-48.

Cope, O. L.

1976. Matthew: A scribe trained for the kingdom of heaven, The Catholic Biblical quarterly monograph series. Washington, D.C: Catholic Biblical Association of America.

DAvies W.D.

1964. The setting of the sermon on the mount. Cambridge: University Press.

DAVies, W.D. \& Allison,.

2004. The Gospel D.C according to Matthew, 3 volumes. International Critical Commentary. Edinburgh: T \& T Clark.

France, R.T.

1998. Matthew, evangelist and teacher. New Testament profiles. Illinois: Intervarsity Press.

2008. The Gospel according to Matthew: an Introduction and Commentary. Leicester: Intervarsity Press.

GARRETT, D.A.

1997. Hosea and Joel. The American commentary, volume 19A. Nashville: Broadman \& Holman

Gerhardsson, B.

1974. Sacrificial service and atonement in the Gospel of Matthew. In R. Banks (ed.). Reconciliation and Hope: New Testament Essays on Atonement and Eschatology; Presented to L.L. Morris on his 60th Birthday. (Exeter: University Press), pp.25-35.

Green, H. B.

1975. The Gospel according to Matthew in the Revised Standard Version, The New Clarendon Bible. London: Oxford University Press.

GUNDRY, R.H. 1994. Matthew: A commentary on his literary and theological art. Grand Rapids: Eerdmans.

HAGNeR, D.A.

1993. Word Biblical Commentary, 33A, Matthew 1-13. Dallas: Word Books. 
HARE, D.R.A.

1993. D.R.A. Matthew. Louisville: John Knox Press.

HILL, D.

1972. The Gospel of Matthew. London: Marshall, Morgan \& Scott.

1978. On the use and meaning of Hosea 6:6 in Matthew's gospel. New Testament Studies 24(1):107-119.

HiNKLE Edin, M.

1998. Learning what righteousness means: Hosea 6:6 and the ethic mercy in Matthew's gospel. Word and World 18(4):355-363.

Hummel, R.

1966. Die Auseinandersetzung zwischen Kirche und Judentum im Matthäusevangelium. München: Kaiser.

KeEnER, G.S.

1999. A commentary on the Gospel of Matthew. Michigan \& Cambridge: Eerdmans.

KILPATRICK, G.D.

1950. The origins of the Gospel according to Matthew. Oxford: Clarendon Press.

KINGSBURY, J.D.

1988. Matthew as story. Philadelphia: Fortress Press.

LIMBURG, J.

1988. Hosea - Micah. Interpretation. Atlanta: John Knox Press.

LOHMEYER, E.

1958. Das Evangelium des Matthäus. Kritisch-exegetischer Kommentar über das Neue Testament. Göttingen: Vandenhoeck \& Ruprecht.Göttingen.

LUZ, U.

1990. Matthew 1-7. A commentary. Edinburgh: T \& T Clark.

2005. Studies in Matthew. Grand Rapids \& Cambridge: Eerdmans.

Macintosh, A.A.

1997. Hosea. A Critical and exegetical commentary. Edinburgh: T \& T Clark.

MCCONNELL, R.S.

1969. Law and prophecy in Matthew's Gospel: The authority and use of the Old Testament in the Gospel of Matthew. Basel: Friedrich Reinhardt Kommissionsverlag.

MEIER, J.P.

1980. Matthew, New Testament message. Dublin: Veritas.

MenKEN, M.J.J.

2004. Matthew's Bible: the Old Testament text of the evangelist. Leuven: University Press. 
MoRRIS, L.

1981. Testaments of love: A study of love in the Bible. Grand Rapids: Eerdmans. 1992. The Gospel according to Matthew. Eerdmans: Michigan.

Moule, C.F.D.

1977. The origin of Christology. Cambridge: University Press.

Mounce, R.H.

1991. Matthew. New International Biblical commentary. Massachusetts: Hendrickson Publishers.

MÜLleR, M.

2001. The reception of the Old Testament in Matthew and Luke-Acts: From interpretation to proof from Scripture. Novum Testamentum 43(4):315-330.

Osborne, G.R.

2010. Matthew. Zondervan exegetical commentary on the New Testament. Grand Rapids: Zondervan.

Overman. J.A.

1996. Church and community in crisis. The Gospel according to Matthew. Pennsylvania: Trinity Press International.

RePsChINSKI, B.

2000. The controversy stories in the Gospel of Matthew: Their redaction, form and relevance for the relationship between the Matthean community and formative Judaism. Göttingen: Vandenhoeck \& Ruprecht.

SALDARINI, A.J.

1991. The Gospel of Matthew and Jewish-Christian conflict. In: D.L. Balch (ed). Social History of the Matthean community. Cross-disciplinary approaches. (Minneapolis: Fortress Press), pp. 38-61.

1994. Matthew's Christian-Jewish Community. Chicago \& London: University of Chicago.

Schlatter, A.

1959. Der Evangelist Matthäus: seine Sprache, sein Ziel, siene Selbstandigkeit; ein Kommentar zum ersten Evangelium. Stuttgart: Calwer

SENIOR, D.

1998. Matthew, Abingdon New Testament Commentaries. Nashville: Abingdon Press.

SмIтH, D.C. 1980 Social Obligation in the Context of Communal Meals. Unpublished Th.D. thesis: Harvard University

Strack, H.L. \& Billerbeck, P. 1965. Kommentar zum Neuen Testament aus Talmud und Midrasch. München: Beck. 
STRECKeR, G.

1971. Der Weg der Gerechtigkeit: Untersuchung zur Theologie des Matthäus. Göttingen: Vandenhoeck \& Ruprecht.

StUART, S.

1987. Hosea-Jonah. Word Biblical commentary, volume 31. Waco: Word Books.

TRILLING, W.

1964. Das wahre Israel. Studien zur Theologie des Matthäuse-Evangeliums. München: Kösel-Verlag.

TURNER, D.L. 2008. Matthew. Baker exegetical commentary of the New Testament. Michigan: Baker academic.

TURNER, N.

1965. Grammatical Insights into the New Testament. Edinburgh: T. \& T. Clark.

VAN Bruggen, J.

1990. Matteüs. Het evangelie voor Israël. Kampen: Kok (Commentaar op het Nieuwe Testament).

VILJOEN, F.P.

2011 The foundational statement in Matthew 5:17-20 on the continuing validity of the Law. In die Skriflig 45(2\&3):385-408.

YANG, Y-E.

1997. Jesus and the Sabbath in Matthew's Gospel. Sheffield: Academic Press. Journal for the Study of the New Testament Supplement Series 139.

ZIMMELI, W.

1985. Xapıs. In G. Friedrich (ed.). Theological Dictionary of the New Testament. (Michigan: Eerdmans), vol 9. pp. 376-402.

Keywords

Mercy

Identity formation

Eat with sinners and tax collectors

Sabbath
Trefwoorde

Barmhartigheid

Identiteitsformasie

Eet met sondaars en tollenaars

Sabbat 